\title{
RESEARCH ON OIL RECOVERY MECHANISMS \\ IN HEAVY OIL RESERVOIRS
}

\section{CONTRACT NO. DE-FG-22-93BC14899}

\author{
Stanford University Petroleum Research Institute \\ Stanford, California
}

Contract Date: February 8, 1993

Principal Investigators

William E. Brigham

Technical Manager SUPRI

Louis M. Castanier

Technical Project Officer (DOE)

Thomas B. Reid

Reporting Period: July 1 - September 30, 1995

\section{OBJECTIVES}

The goal of the Stanford University Petroleum Research Institute is to conduct research directed toward increasing the recovery of heavy oils. Presently, SUPRI is working in five main directions:

1. FLOW PROPERTIES STUDIES - To assess the influence of different reservoir conditions (temperature and pressure) on the absolute and relative permeability to oil and water and on capillary pressure.

2. IN-SITU COMBUSTION - To evaluate the effect of different reservoir parameters on the in-situ combustion process. This project includes the study of the kinetics of the reactions.

3. STEAM WITH ADDITIVES - To develop and understand the mechanisms of the process using commercially available surfactants for reduction of gravity override and channeling of steam.

4. FORMATION EVALUATION - To develop and improve techniques of formation evaluation such as tracer tests and pressure transient tests.

5. FIELD SUPPORT SERVICES - To provide technical support for design 蓜d

monitoring of DOE sponsored or industry initiated field projects.

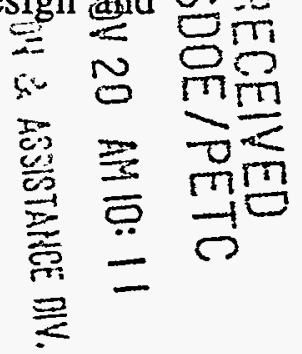




\section{DISCLAIMER}

This report was prepared as an account of work sponsored by an agency of the United States Governmeat. Neither the United States Government nor any agency thereof, nor any of their empioyees, makes any warranty, express or implied, or assumes any legal liability or responsibility for the accuracy, completeness, or usefulness of any information, apparatus, product, or process disciosed, or represents that its use would not infringe privately owned rights. Reference herein to any specific commerciai product, process, or service by trade name, trademark, manufac: turer, or otherwise does not necessarily constitute or imply its endorsement, recommendation, or favoring by the United States Government or any agency thereof. The views and opinions of authors expressed herein do not necessarily state or reflect those of the United States Government or any agency thereof. 


\section{GENERAL INFORMATION}

The Nineteenth Annual Report was published by DOE.

Two papers were presented:

1. A paper titled, "A Preliminary Study of Relative Permeability in Geothermal Rocks," by C. Satik, W. Ambusso, L. Castanier and R. Horne, was presented at the Annual Geothermal Resources Council Meeting, Reno (October 8-11, 1995).

2. A paper titled, "The Effect of Low Temperature Oxidation on Fuel and Produced Oil During In-situ Combustion," by D. Mamora and W.E. Brigham has been submitted for publication in In-situ Journal.

\section{PROJECT 1 Flow Properties Studies}

The report on end effects during unsteady state oil/water displacement experiments has been delayed because of difficulties in setting up communication by computer with the researcher, who is now working overseas. As soon as this problem is solved, the final draft will be written, produced and submitted for review.

During the quarter we calibrated the $\mathrm{CT}$ scanner for three phase saturation measurements. This work is essentially complete. Preliminary design is underway on the positioning system for scanning in the vertical mode.

Construction is complete on a flow system for isothermal studies of flow through fractured media. Local porosities were determined by water saturation and by scanning. The two methods gave results very close to each other. The model was saturated by water and the imbibition process was observed by the CT scanner. These preliminary results will be described in a topical report scheduled for the Spring of 1996.

Construction of the equipment for steam/water relative permeability studies is done. Preliminary runs on nitrogen/water systems are described in the paper referenced in the General Information section.

\section{PROJECT 2 In-Situ Combustion}

The report describing five in-situ combustion tube runs with Saudi tar and metallic additives is being expanded to include two other runs with a different oil. The two new tube runs involve a sulfur rich Middle Eastern oil. One of the runs is a control run, and the other contained tin as a metallic additive. One of our industry associates has 
performed spectroscopic analysis of the products of combustion. The burned cores, as well, as the combustion products, are now analyzed in detail to better understand the additive transport and the combustion process. It appears that, at the end of the run, most of the tin remains distributed in the sandpack as tin oxide. Future experiments will look at injection of a slug of additive solution to study transport mechanisms of the metallic salts.

\section{PROJECT 3 Steam Injection With Additives}

Interpretation is progressing on the waterflood and steamflood experiments in the three-dimensional model with oil present. Good saturation data were obtained by the CT scanner, and verification will be done using mass and heat balances on the model. A preliminary report on these results is expected by Winter, 1996.

The report on the steam injection experiments in fractured media is essentially complete. An abstract of a paper on this work was accepted for presentation at the SPE/DOE Meeting on Enhanced Oil Recovery in April, 1996. Submission of the technical topical report is expected by the end of 1995.

The draft report on the observations of foam flow at low surfactant concentration in realistic sized silicon micromodels had to be modified for calculation of the micromodel permeability. This report will be sent to DOE for review by December 1995 . A new researcher will continue this project. His first task will be to study three phase flow mechanisms at the pore level.

\section{PROJECT 4 Formation Evaluation}

No work was performed on this subject during this reporting period.

\section{PROJECT 5 Field Support Services}

A paper will be presented at the International Energy Agency meeting in October 1995. This summarizes work done on the steam drive project in the Wilmington Field. Previous work consisted of heat balance calculations and determination of the heat losses. The extension of this work includes an economic analysis and a risk evaluation using 
Monte Carlo simulation on both the technical and economic variables. A report on this project is being drafted.

Reports on injectivity and flow in doublets by W.E. Brigham are in the draft stage, and will be submitted for publication in the Winter of 1996. 